\title{
Flood Hazard Mapping in Residential Area Using Hydrodynamic Model HEC-RAS 5.0
}

\author{
M. B. Al Amin ${ }^{a^{*}}$, R. S. Ilmiaty ${ }^{a}$ A. Marlina ${ }^{b}$ \\ ${ }^{a}$ Civil Engineering Department and Planning, University of Sriwijaya, Indonesia \\ ${ }^{b}$ Civil Engineering Department, University of Tridinanti, Indonesia
}

\section{Article Info:}

Received: 30 September 2019 in revised form: January 2019 Accepted: March 2019

Available Online: 7 July 2020

\section{Keywords:}

Flood hazard, Flood risk, Flood simulation, HEC-RAS, GIS

\section{*Corresponding Author:}

M. B. Al Amin

Civil Engineering Department and Planning, University of Sriwijaya, Ogan Ilir, Indonesia Email: baitullah@unsri.ac.id

\begin{abstract}
The flood hazard rating is one of the essential variables in flood risk analysis. The identification of flood-prone areas urgently requires information about flood hazard zones. This research explains the method to develop flood hazard maps by using hydrodynamic modeling in residential areas. The hydrodynamic model used in this research is HEC-RAS 5.0, which can simulate the one- and two-dimensional flow regimes. The study area is Bukit Sejahtera and Tanjung Rawa residences located in Palembang City with a total area of about $200 \mathrm{ha}$, where the Lambidaro River was frequently overflowing caused flood inundation in the area. There are five indicators of flood hazard being analyzed, i.e., 1) flood depth, 2) flow velocity, 3) energy head, 4) flow force, which is the result of multiplication between flood depth and the square of flow velocity, and 5) intensity, which is the result of multiplication between flood depth and the flow velocity. The simulation results show that the flood hazard rating in the study area ranges from high to low level. The zones with a high flood hazard rating are dominated by the area around or near the river, whereas the further zones have a moderate and low flood hazard rating. The flood depth indicator has a more significant influence than the flow velocity on the flood hazard level in the study area. This research is expected can contribute to the development of flood maps and flood control methods in advance.
\end{abstract}

\section{INTRODUCTION}

Flood control is the effort that must be made in order to minimize the impacts and losses due to floods. The formulation of a flood control strategy substantially requires a flood risk map that shows locations and areas with high, medium, and low flood risk levels. Solin \& Skubincan (2013) stated that the level of flood risk in an area is a function of flood hazards, vulnerability, and adaptive capacity. If the levels of flood hazard and vulnerability are high, while the level of capacity is low, an area will have a high-risk level. Conversely, if the level of capacity is high, even though the levels of hazard and vulnerability are high, the level of risk of flooding can be low.

The standard methods and guidelines in the development and classification of flood hazard levels in Indonesia are not currently available in detail. The available guidelines are still general, as stated in the Regulation of the Head of The National Agency for Natural Disaster Countermeasure, abbreviated as BNPB, is the Indonesian board for natural disaster affairs, No. 2 the Year 2012 concerning General Guidelines for Disaster Risk Assessment. Even research related to this is also still minimal.

Several previous studies related to flood hazard analysis and risk are still limited to simple spatial methods (Elkhrachy, 2015; Oubennaceur et al., 2018; Ovando et al., 2018; Ozkan \& Tarhan, 2016; Rahman \& Thakur, 2018; Zhang et al., 2015). It causes many variables relating to the characteristics of floods, which are very important to be unavailable. This study fills this gap by using the HEC-RAS model which focuses on 
hydraulic analysis. The determination of the flood hazard level is very closely related to the hydraulic parameters. Wallingford (2005) explained that the flood hazard is a function of inundation depth, flow velocity, and debris flow factor. To obtain these parameters can only be done through a flood modeling and simulation using the hydrodynamic model.

The flood inundation simulations based on hydrodynamic models are generally carried out using a one or two-dimensional flow regime and a combination of both (integrated one-dimensional and twodimensional). The advantage of the one-dimensional model compared to the two-dimensional is a fast and simple simulation, while the disadvantage is hydraulic variables such as flow velocity and flow time cannot be described in terms of time and spatial functions. The flood inundation map generated from the onedimensional flow model can only provide information about the distribution and depth of the inundation, while another parameter such as flow velocity cannot be described. The mapping of flood hazards using various hydraulic parameters can only be done with two-dimensional flow models (Al Amin \& Haki, 2017).

This paper discusses the flood hazard mapping method using a one- and two-dimensional flow-based hydrodynamic model using HEC-RAS 5.0. The objective of this study is to illustrate how each hydraulic parameter affects the level of flood hazard. The study area took two residential areas, with a total area of $200 \mathrm{ha}$. It is intended to limit the area so that it only focuses on residential areas that are not too large, and also the results obtained can be more thorough (micro-scale). Besides, to simulate a large area requires very high computer specifications and considerable time and effort. However, the same method also can be applied to a broader area. The hydraulic parameters being used as indicators and thresholds in the classification of flood hazard ratings in this study are inundation depth, flow velocity, energy head, intensity, and flow force.

\section{DATA AND METHODS}

This research was conducted at Bukit Sejahtera and Tanjung Rawa residential area located in Palembang City, South Sumatra, as shown in Figure 1. The study area is a former swampland converted into a residential area since the beginning of 1990 (Situngkir et al., 2014). In the west, both residential areas are directly adjacent to the Lambidaro River, which is a tributary that flows into the Musi River. Because the study area is located in the lower reaches of the river, the flood discharge and river tides often cause inundation in both areas.

The modeling and simulation of flood inundation were carried out through a series of hydrological and hydraulic analyses. The hydrological analysis aims to produce peak flood discharge ( $Q p)$ with the principle of rainfall-runoff, while the hydraulic analysis aims to produce hydraulics flow parameters such as water surface elevation (WSE), flow velocity, flow time, and other flow variables with the principle of a combination of one- and two-dimensional flow. The hydraulic simulation results are then integrated with geographic information systems to produce a flood map. Figure 2 illustrates the general stages of flood modeling to produce a flood map.

\subsection{Flood Hazard Indicators}

Several hydraulic indicators can be used to classify the level of flood hazards. Ribeiro Neto et al.(2016) recommended the flood hazards mapping by using indicators based on depth and flow velocity. There are five suggested indicators, namely flow depth, flow velocity, energy head, intensity, and flow force. The last three indicators are a combination of flow depth and velocity formulated as:

$$
\begin{aligned}
& \text { Energy head }=d+v^{2} / 2 g(\mathrm{~m}) \\
& \text { Intensity }=d \cdot v\left(\mathrm{~m}^{2} / \mathrm{s}\right) \\
& \text { Flow force }=d \cdot v^{2}\left(\mathrm{~m}^{3} / \mathrm{s}^{2}\right)
\end{aligned}
$$

where:

$d:$ flow depth $(m)$

$v$ : flow velocity $(\mathrm{m} / \mathrm{s})$

$g$ : gravitational acceleration $\left(\mathrm{m} / \mathrm{s}^{2}\right)$ 
Table 1 below provides a range of flood hazard levels for each indicator. These levels are divided into three, namely low, medium, and high ratings.

Table 1. Range of flood hazard indicators (adapted from Ribeiro Neto et al., 2016)

\begin{tabular}{llll} 
Indicators & Low & Medium & High \\
\hline Flow depth $(\mathrm{m})$ & $0-0.60$ & $0.60-1.20$ & $>1.20$ \\
\hline Flow velocity $(\mathrm{m} / \mathrm{s})$ & $0-0.60$ & $0.60-1.20$ & $>1.20$ \\
\hline Energy head $(\mathrm{m})$ & $0-1.00$ & $1.00-2.00$ & $>2.00$ \\
\hline Flow force $\left(\mathrm{m}^{3} / \mathrm{s}^{2}\right)$ & $0-1.00$ & $1.00-2.00$ & $>2.00$ \\
\hline Intensity $\left(\mathrm{m}^{2} / \mathrm{s}\right)$ & $0-0.36$ & $0.36-1.50$ & $>1.50$ \\
\hline
\end{tabular}

Table 2 shows the influence of flood hazard indicators on the damage caused. Each indicator has a different effect on the structure of residential buildings, road structure, monetary losses of residential buildings, losses of road infrastructure, and disruption of social and economic activities. For example, the indicator of flow velocity has a strong impact on the structural damage to roads, while the flow depth indicator has a strong influence on the structural damage of residential buildings.

Table 2. The influence of hydraulic indicators on flood damages (adapted from Kreibich et al., 2009 in Ribeiro Neto et al., 2016)

\begin{tabular}{llllll}
\hline $\begin{array}{l}\text { Impact } \\
\text { indicators }\end{array}$ & $\begin{array}{c}\text { Structural } \\
\text { damage of } \\
\text { residential } \\
\text { buildings }\end{array}$ & $\begin{array}{c}\text { Structural } \\
\text { damage to } \\
\text { roads }\end{array}$ & $\begin{array}{c}\text { Damage Types } \\
\text { Monetary } \\
\text { losses to } \\
\text { residential } \\
\text { building }\end{array}$ & $\begin{array}{c}\text { Monetary } \\
\text { losses to road } \\
\text { infrastructure }\end{array}$ & $\begin{array}{c}\text { Business } \\
\text { interruption } \\
\text { and duration }\end{array}$ \\
\hline Flow velocity & No & Strong & Weak & No & No \\
\hline Water depth & Strong & Medium & Medium & No & Medium \\
\hline Energy head & Strong & Medium & Medium & No & Weak \\
\hline Flow force & Weak & Strong & Weak & No & No \\
\hline Intensity & Weak & Strong & Weak & No & Weak \\
\hline
\end{tabular}

\subsection{Hydrodynamic Model HEC-RAS 5.0}

Brunner et al. (2015) explained that the Hydrologic Engineering Center's - River Analysis System abbreviated as HEC-RAS, is the most widely used river hydraulic model software in the world. Initially, HECRAS was only able to simulate one-dimensional flow only. However, with the increasing need for one- and two-dimensional flow models, HEC-RAS 5.0 has currently been able to simulate one- and two-dimensional flow regimes. Several previous studies that succeeded in simulating one- and two-dimensional flow using HEC-RAS 5.0 were among those conducted by Quirogaa et al. (2016) and Patel et al. (2017). The HEC-RAS software is a public domain that can be downloaded through its official website at http://www.hec.usace.army.mil/software/hec-ras/.

The HEC-RAS 5.0 model uses the Saint Venant equation or Wave Diffusion for two-dimensional flow. In general, the Wave Diffusion equation provides a faster and more stable solution, while the Saint Venant equation is more applicable to a broader range of hydraulic problems. Users are given the freedom to choose the equations they will use. In detail, these equations are given in the HEC-RAS Hydraulic Reference Manual (Brunner, 2016). 


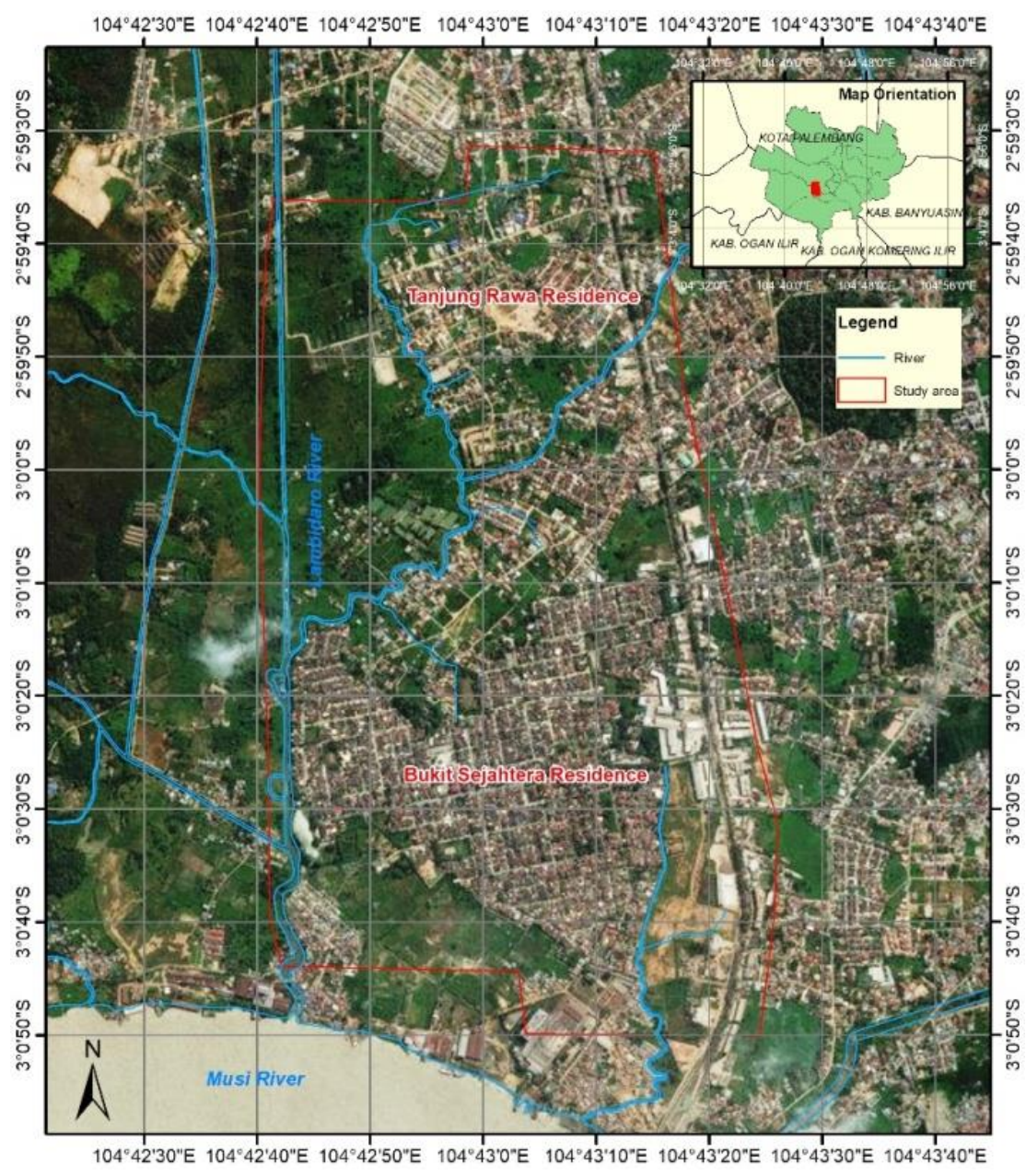

Figure 1. Study area

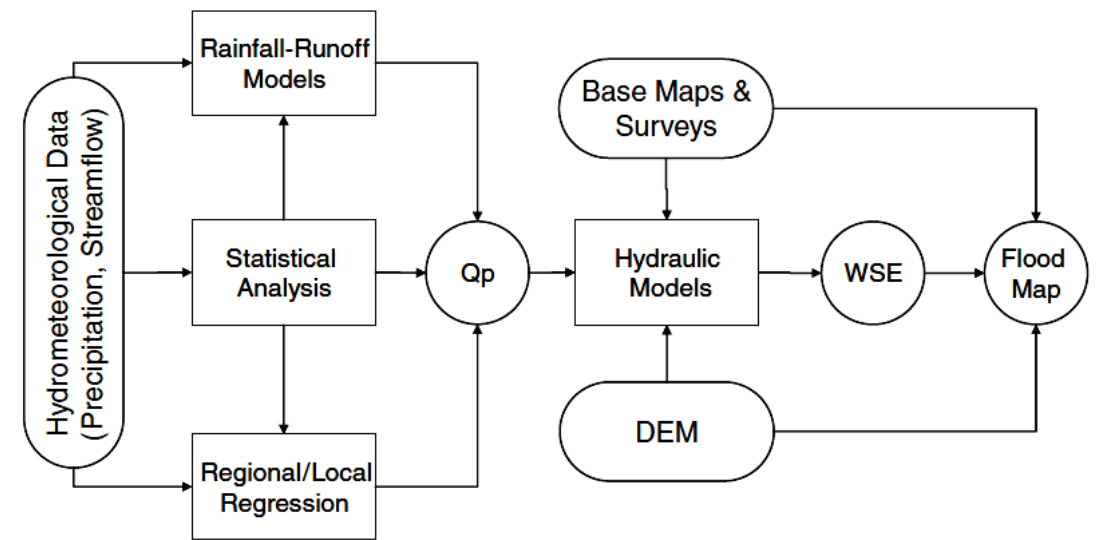

Figure 2. A flowchart to produce a flood map (adapted from National Research Council, 2009)

This paper only focuses on simulating the flood hazard rating generated for each hydraulic indicator mentioned earlier. Therefore, an explanation of the hydrological and hydraulic analysis methods used will not be discussed in more detail here. The detail hydrological modeling and simulation used in this study have been described in the previous study conducted by Al Amin et al. (2015), while the hydraulic model and the simulation used in this study in detail can be found in Al Amin et al. (2018). The data used in the hydrological analysis include rainfall intensity, river discharge, topography, river network, land use/cover, and soil type, whereas the data used in the hydraulic analysis consists of channel cross-sections, tidal water level, land cover, base map, and digital elevation model (DEM). 


\section{RESULTS AND DISCUSSION}

\subsection{A framework to Generate Flood Hazard Maps}

The flood hazard mapping in this research is carried out in stages using an integrated framework. Figure 3 below shows the flood hazard mapping framework developed and proposed in this study represented as a flowchart. The framework is the development of the flow chart described earlier in Figure 2. The stages begin with hydrological modeling and simulation to produce flood hydrographs. Besides, the tide level is generated using a tidal forecasting analysis based on a continuous water level measurement. The flood hydrographs and tide levels are then used as boundary conditions at upstream (as flow hydrograph) and downstream (as stage hydrograph), respectively, in the hydraulic modeling and simulation, as shown in Figure 4a. The one-dimensional flow of hydraulic simulation produces a floodwater profile along the river reaches, which is then connected with a two-dimensional model, namely 2-D Areas in HEC-RAS 5.0, using lateral structures. The combination of one- and two-dimensional flow simulation will generate flood inundation on a floodplain with various hydraulic parameters, as given in Figure 4b. The hydraulic parameters generated from the simulation are then used as indicators or flood thresholds to produce flood hazard maps.

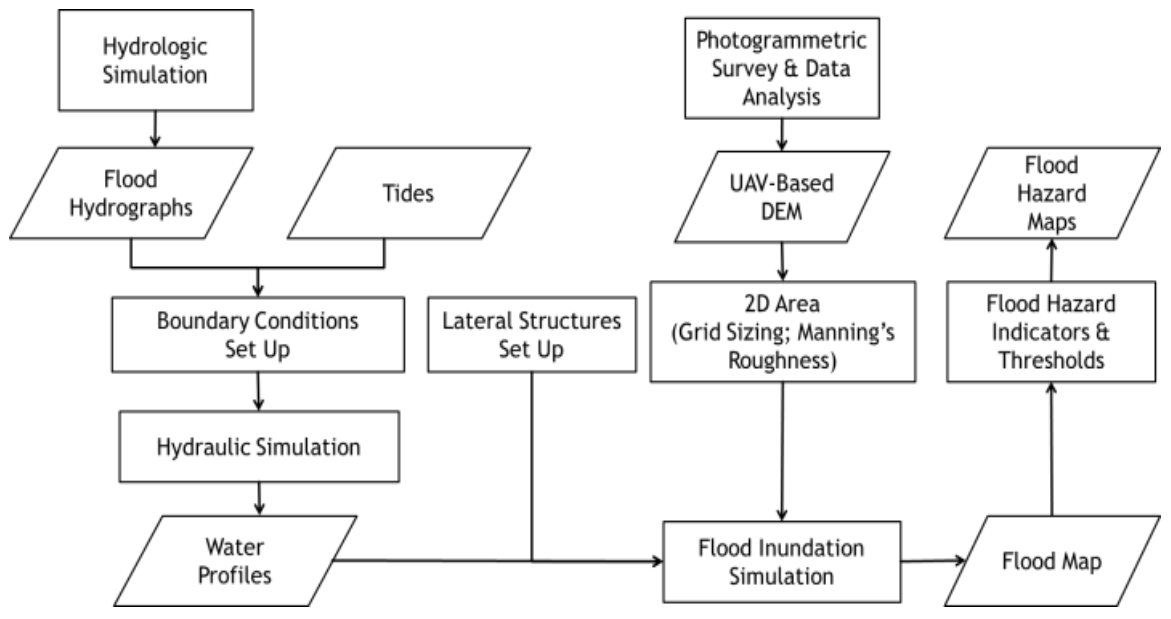

Figure 3. A proposed framework to produce flood hazard maps

\subsection{Model Accuracy Test}

The model accuracy test has been carried out and explained in detail in the previous study conducted by Al Amin et al., (2018) by comparing the simulated inundation depths with the observed one. The observed inundation depths in the field were obtained by interviewing residents and tracking flood trails observed in buildings, houses, and other objects. There were 41 observation points analyzed, as described Al Amin et al., (2018). Figure 5 below shows the relationship of comparison between the simulated inundation depths and observed depths. The model test accuracy parameter used is the root mean square error (RMSE), with the value obtained, which is 0.379 . The resulted RMSE value is quite small, which indicates that the inundation depths of the simulation and observation results have values that are similar or close to each other. Thus, the accuracy of the flood inundation model can be said to be quite good, and the results can be trusted. 

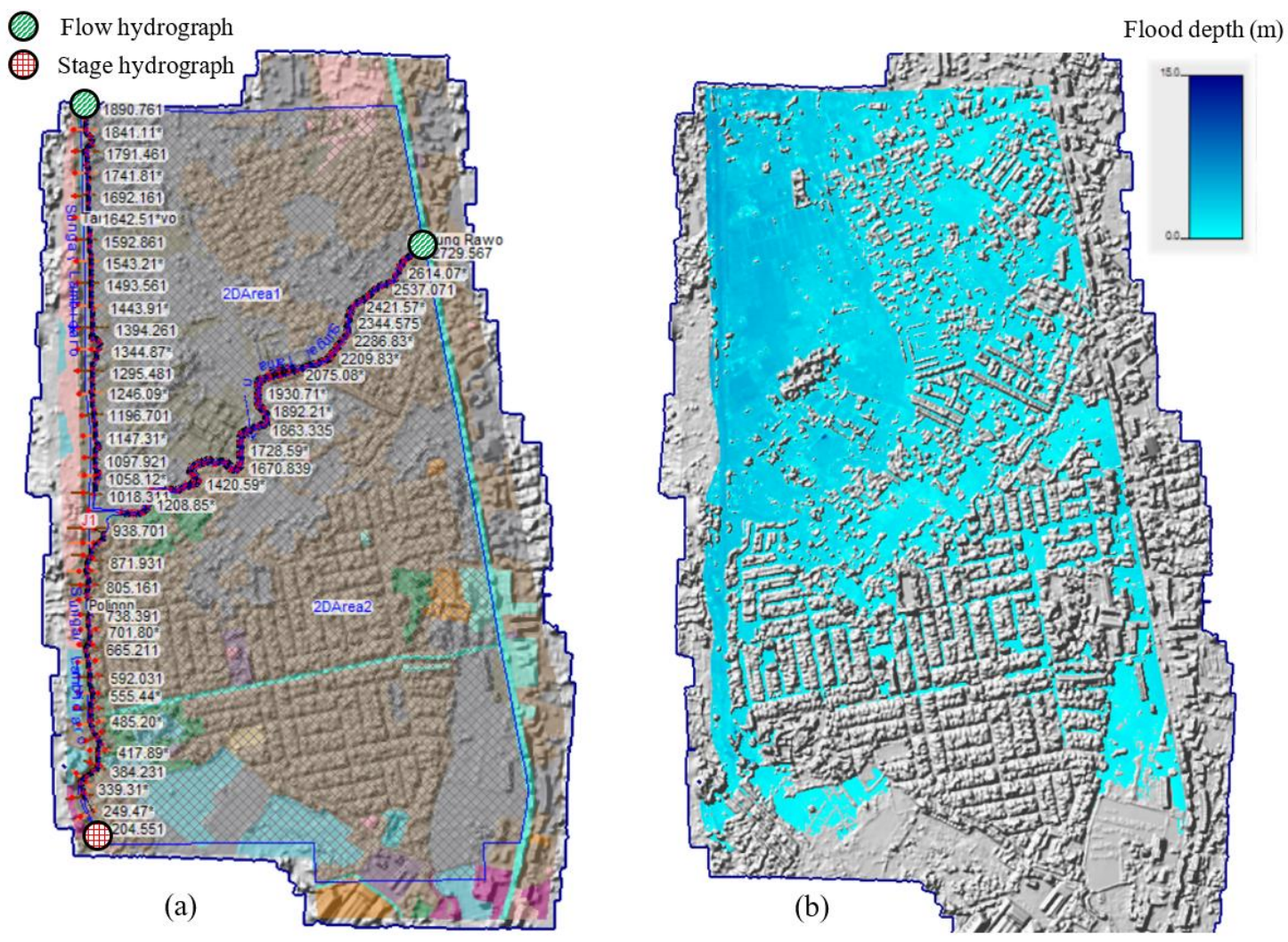

Figure 4. The geometry model for river reaches (1-D domain) and floodplain (2-D domain) in HEC-RAS (a), the simulation result shows flood inundation visualized in RAS Mapper (b) (adapted from Al Amin et al.,

2018)

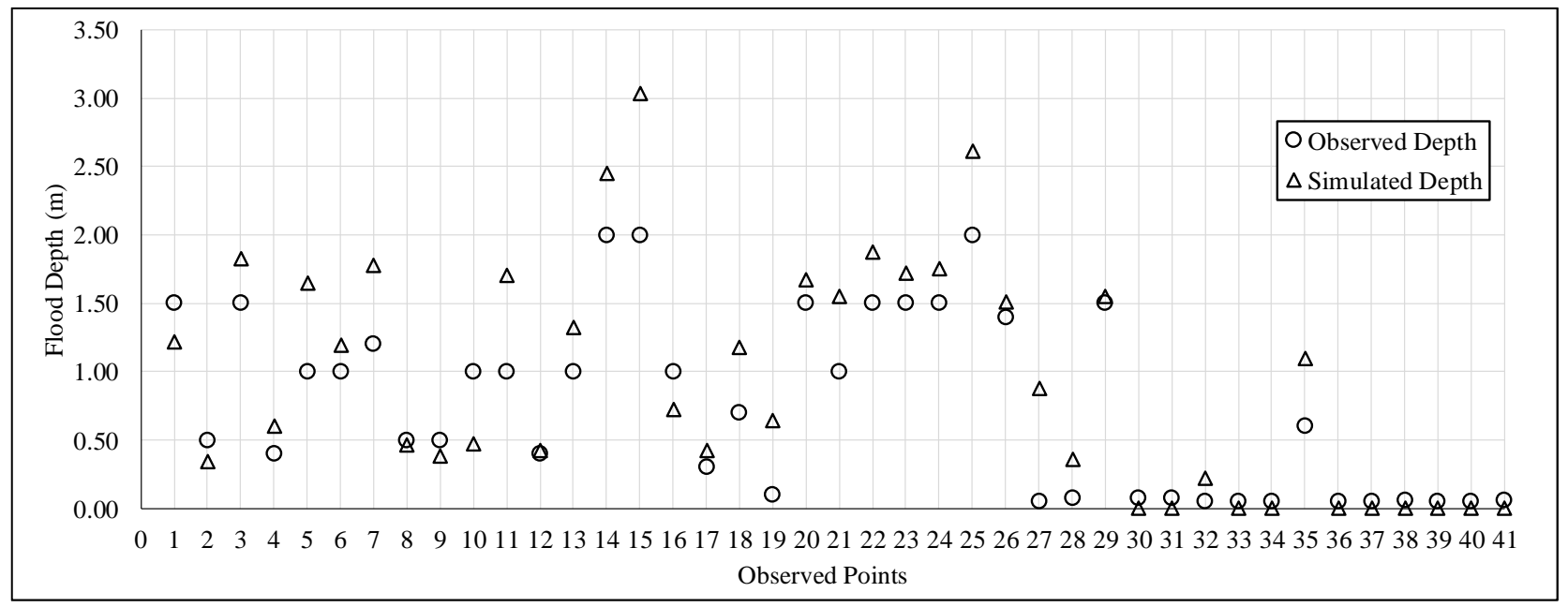

Figure 5. The comparison of the simulated and observed depths (adapted fromAl Amin et al., 2018)

\subsection{Inundation Depth}

The simulation results of HEC-RAS 5.0 show that the inundation depths in the study area are varied, of which for Bukit Sejahtera residence between $0-1.50 \mathrm{~m}$ and Tanjung Rawa residence $0-4.25 \mathrm{~m}$. Figure 6 shows the map of inundation depths and the flood hazard rating based on the threshold given in Table 1 earlier. From the figure, it can be seen that the high inundation depths likely occur in the area near the river. It is because the topography of the area has a lower elevation compared to other areas. The flood hazard level based on inundation depth indicators in the study area shows a high value because most areas 
have inundation depths of more than $1.20 \mathrm{~m}$, especially in Tanjung Rawa residence. Figure 11 shows the distribution of pixel values from raster data analyzed using a geographic information system for each flood hazard indicator. The average inundation depth in the study area is $1.916 \mathrm{~m}$ represented by a dashed line, as shown in Figure 11.

\subsection{Flow Velocity}

The flow velocity of the simulation results in the study area is given in Figure 7. The high flow velocities likely occur around the tributary of the Lambidaro River. It is because the smaller channel size tends to cause the flow velocity to be higher. The flow velocities in the study area range from $0-5.50 \mathrm{~m} / \mathrm{s}$. Because most of the surface velocities are at low rates, the flood hazard level based on the flow velocity indicator in the study area is dominated by low levels. The average flow velocity is $0.621 \mathrm{~m} / \mathrm{s}$, as shown in Figure 11 .

\subsection{Energy Head}

The energy head is a function of the sum of the hydraulic head and kinetic head. This energy head is also known as specific energy. Figure 8 shows the energy head of the flood flow and flood hazard level in the study area. At a high depth, the flow velocity will be low, so the energy head is more influenced by the flow depth parameter. On the contrary, at a low depth, the influence of flow velocity is more dominant. Based on Figure 8, it is obtained that the energy head in the study area ranges from $0-4.50 \mathrm{~m}$. The flood hazard level based on energy head indicators is in medium to high rating, especially in areas around the river. The average energy head in the study area is $1.912 \mathrm{~m}$, as shown in Figure 11.

\subsection{Intensity}

The flood intensity is the result of multiplication between inundation depth and flow velocity. Figure 9 shows the map of flood intensities along with the flood hazard level. From the figure, it can be seen that the flood intensity in the study area ranges from $0-3.00 \mathrm{~m}$. The level of flood hazard in the study area based on the intensity indicators is dominated by a low rating. The level of medium to high flood hazard likely occurs around rivers and areas with lower topography. It is due to the hydraulic factors, i.e., depths and flow velocities have the same impact on the value of flood intensities. The average flood intensity in the study area is $0.335 \mathrm{~m} 2 / \mathrm{s}$, as given in Figure 11 .

\subsection{Flow Force}

Unlike the intensity, the flow force is the multiplication of the inundation depth and the square of flow velocity. Thus, the influence of the flow velocity is greater than the inundation depth. The flow force map and the flood hazard level for the study area are given in Figure 10. From the figure, it can be seen that the flow force ranges from $0-5.50 \mathrm{~m} 3 / \mathrm{s} 2$. The level of flood hazard in the study area based on flow force indicators is mostly low. The medium level to a high flood hazard likely occurs around the river. The average flow force in the study area is $0.586 \mathrm{m3} / \mathrm{s} 2$, as shown in Figure 11 . 

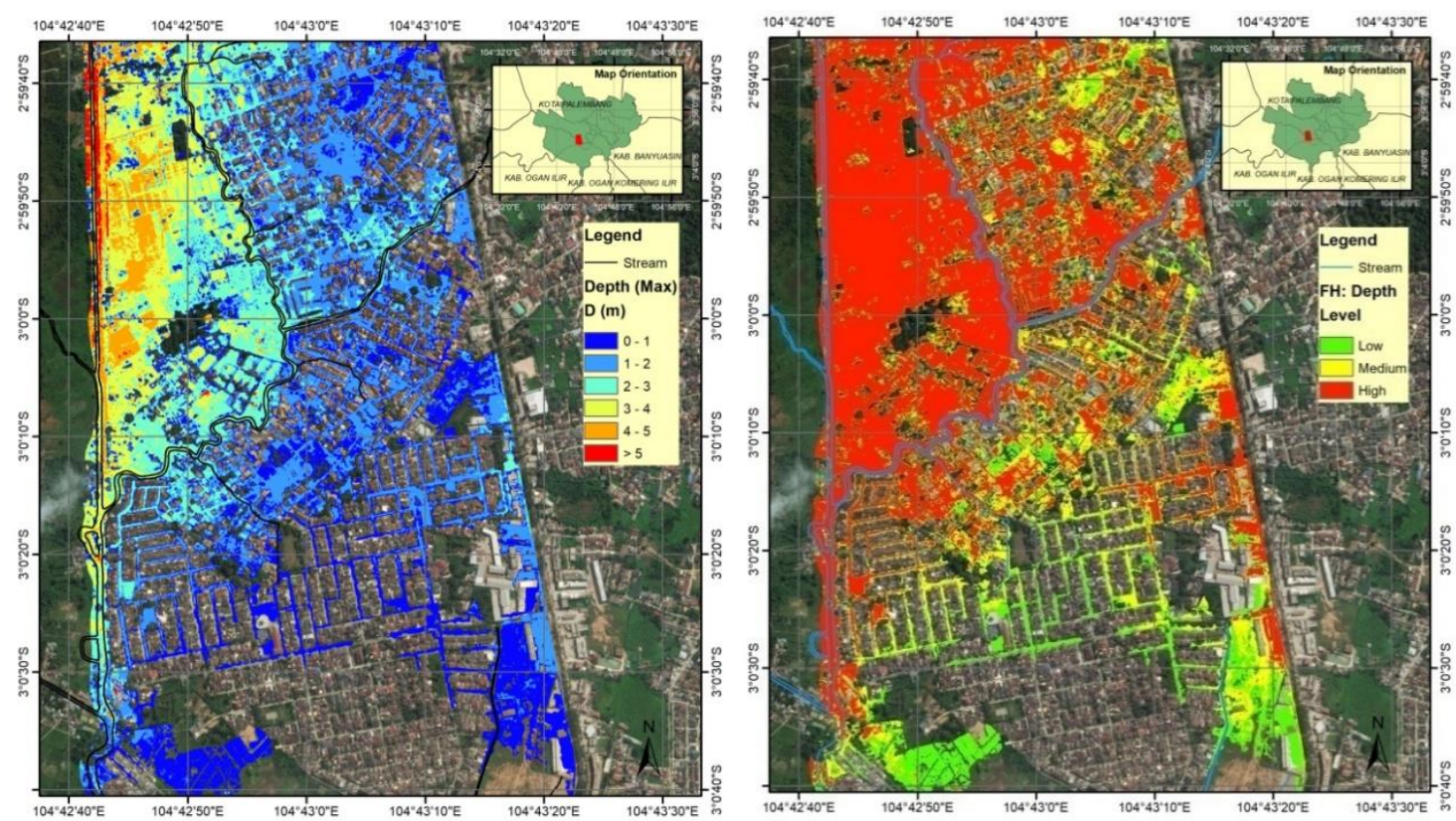

Figure 6. The inundation depth map (left) and based flood hazard level (right). Low hazard: depth $=0-0.60$ $\mathrm{m}$, medium hazard: depth $=0.60-1.20 \mathrm{~m}$, and high hazard: depth $>1.20 \mathrm{~m}$
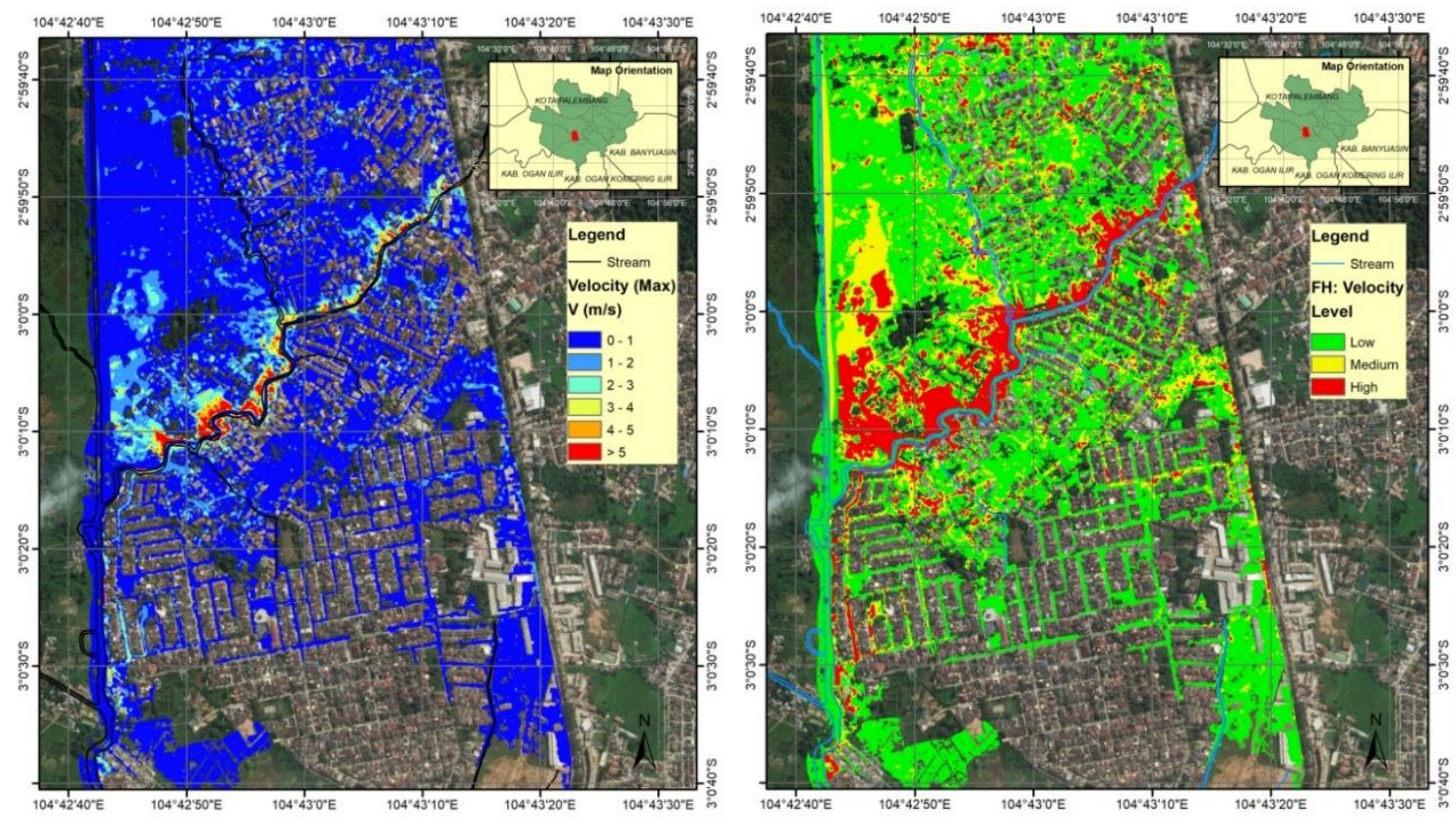

Figure 7. The flow velocity map (left) and based flood hazard level (right). Low hazard: velocity $=0-0.60$ $\mathrm{m} / \mathrm{s}$, medium hazard: velocity $=0.60-1.20 \mathrm{~m} / \mathrm{s}$, and high hazard: velocity $>1.20 \mathrm{~m} / \mathrm{s}$ 

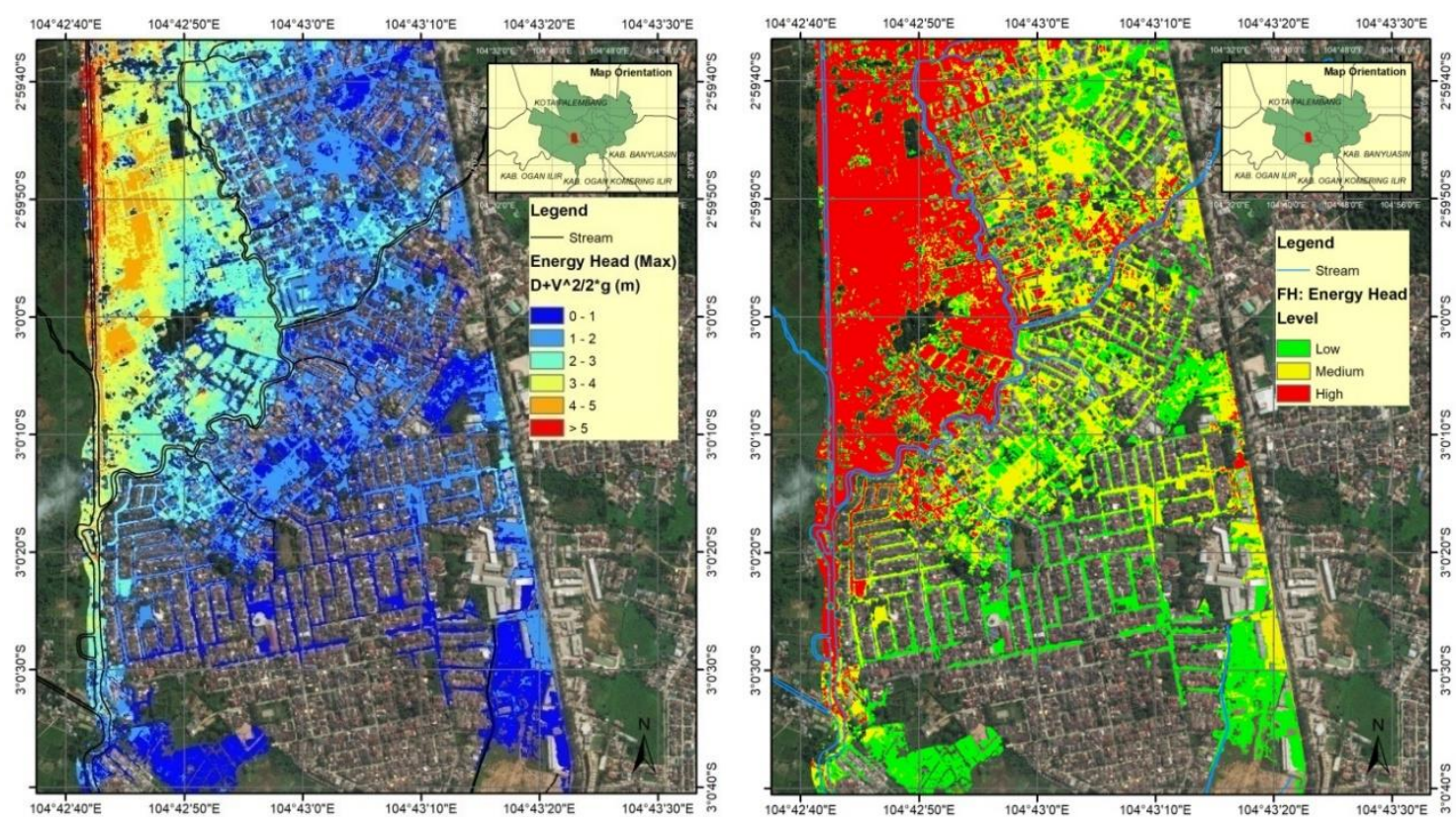

Figure 8. The energy head map (left) and based flood hazard level (right). Low hazard: energy head = $0-$ $1.00 \mathrm{~m}$, medium hazard: energy head $(1.00-2.00 \mathrm{~m})$, high hazard: energy head $>2.00 \mathrm{~m}$
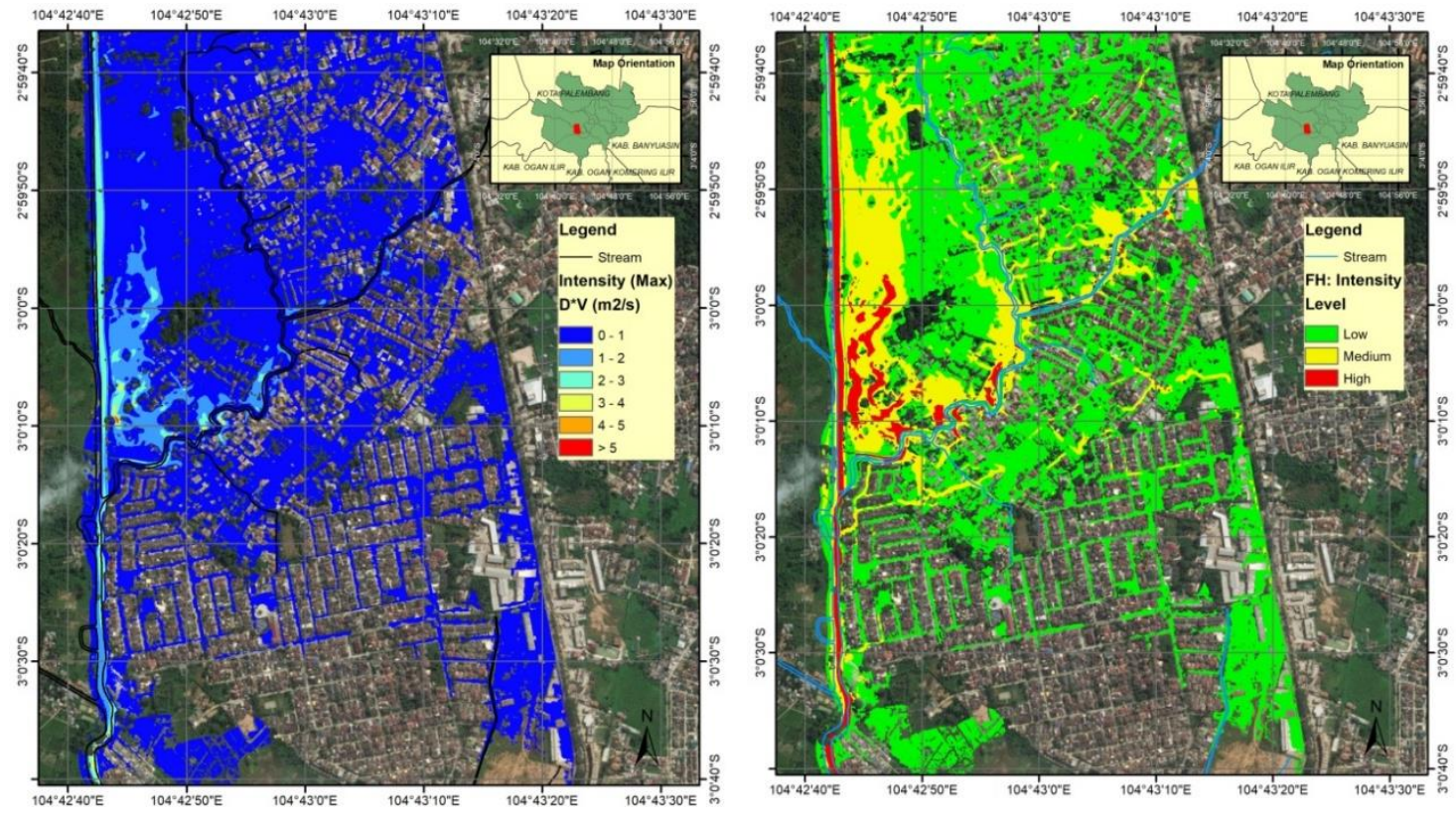

Figure 9. The flow intensity map (left) and based flood hazard level (right). Low hazard: intensity $=0-0.36$ $\mathrm{m}^{2} / \mathrm{s}$ ), medium hazard: intensity $=0.36-1.50 \mathrm{~m}^{2} / \mathrm{s}$, and high hazard: intensity $>1.50 \mathrm{~m}^{2} / \mathrm{s}$ ) 

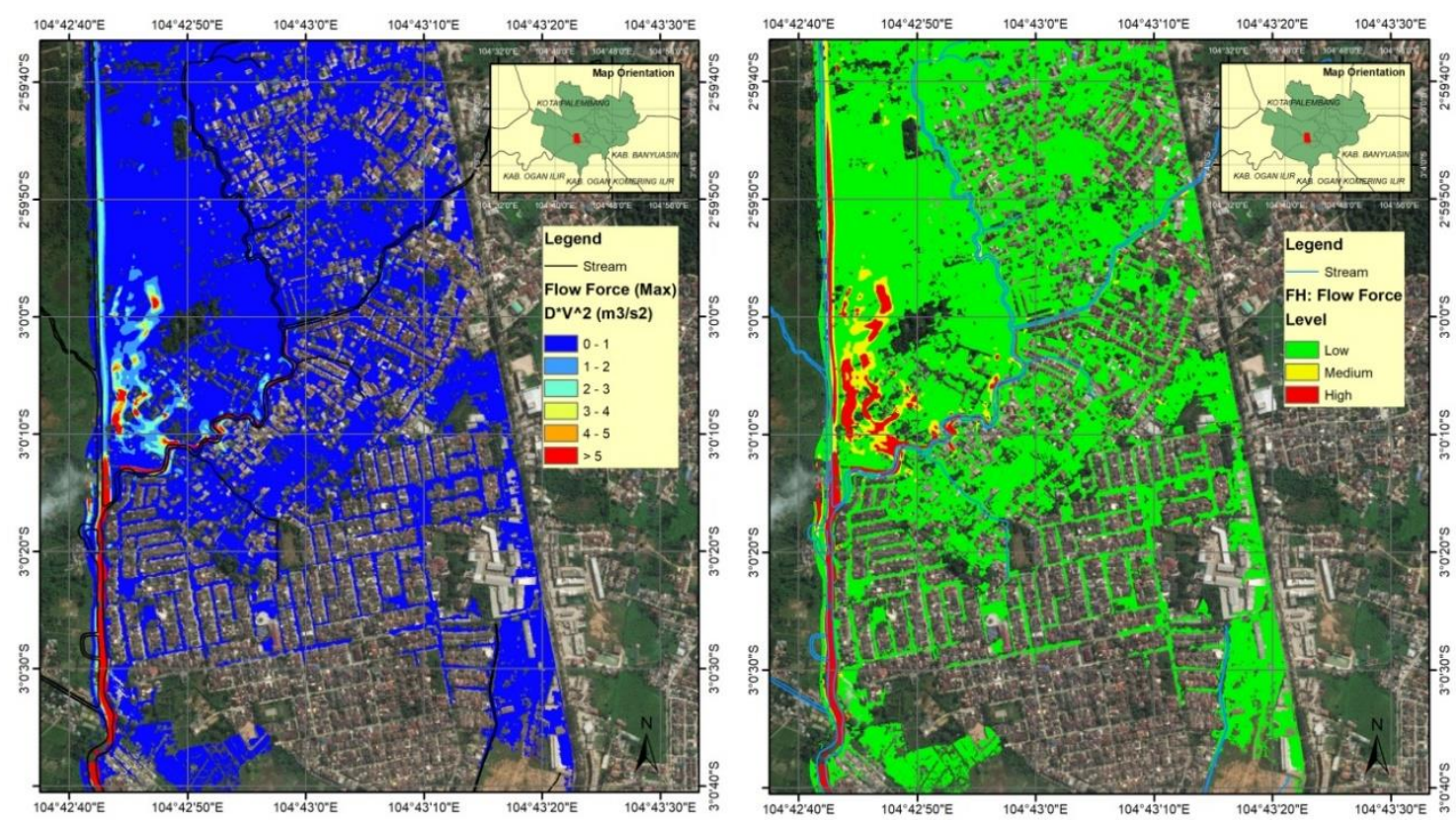

Figure 10. The flow force map (left) and based flood hazard level (right). Low level: flow force $=0-1.00$ $\mathrm{m}^{3} / \mathrm{s}^{2}$, medium hazard: flow force $=1.00-2.00 \mathrm{~m}^{3} / \mathrm{s}^{2}$, and high hazard: flow force $>2.00 \mathrm{~m}^{3} / \mathrm{s}^{2}$

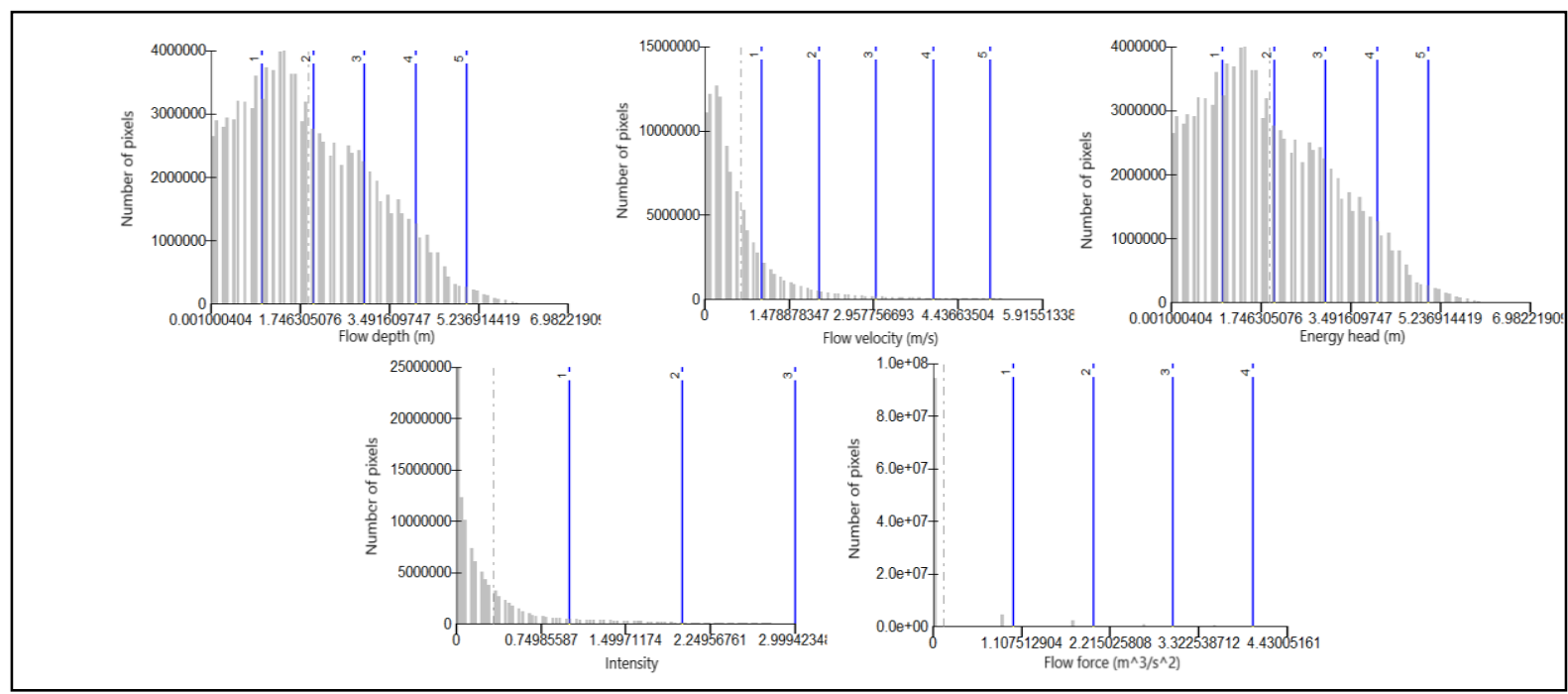

Figure 11. The distribution of pixel values for each flood hazard indicator. Average depth $=1.916 \mathrm{~m}$, average flow velocity $=0.621 \mathrm{~m} / \mathrm{s}$, average energy head $=1.912 \mathrm{~m}$, average intensity $=0.335 \mathrm{~m}^{2} / \mathrm{s}$, and average flow force $=0.586 \mathrm{~m}^{3} / \mathrm{s}^{2}$

There are five flood hazard indicators analyzed in this study, i.e., inundation depth, flow velocity, energy head, intensity, and flow force. Based on the results of the analysis, it was found that the level of flood hazard in the study area based on the depth indicator was dominated by a high rating, while based on the indicator, the flow velocity was dominated by a low rating. The other indicators are based on a combination of depth and flow velocity; namely, energy head generates flood hazard levels that vary from medium to high, while indicators of intensity and flow force both generate low flood hazard levels. Thus, the inundation depth factor more influences the level of flood hazard in the study area than the flow velocity. It can occur due to the leading cause of the flooding is the high tide of the river, which is higher than the ground elevation in several study areas. The influence of flow velocity on flood hazard level is only dominant in the rivers and surrounding banks. 
Based on Table 2, which classifies the impact of flood hazard indicators on the level of flood damages, it can be stated that the inundation depth indicator, whose influence is more dominant in the study area, has the potential to cause more damage to the structure of house buildings. Besides, the impact can also be at a medium level to cause road damage, monetary losses of the residential building, and business interruption and duration. The recommended flood control priorities for the study area are the construction of flood dikes and sluice gates to control the tide level of the river. Also, retention ponds and swamps should also be maintained and optimized as reservoirs for the surface runoff.

\section{CONCLUSION}

The flood hazard maps can be generated through hydraulic modeling using HEC-RAS 5.0 integrated with geographic information systems. The five flood hazard indicators that can be used are inundation depth, flow velocity, energy head, intensity, and flow force. The resulted flood hazard map shows that the study area has a high to low hazard level. The areas with high to medium hazard levels are located around rivers and surrounding areas with elevations lower than floodwaters. The inundation depth indicator has a more significant influence than the flow velocity in determining the level of flood hazard in the study area. This study has succeeded in developing the flood hazard maps based on the hydrodynamic model using HECRAS 5.0. Thus, the results of this study are expected to be useful in the development of subsequent flood control methods.

\section{ACKNOWLEDGMENTS}

This article's publication is supported by the United States Agency for International Development (USAID) through the sustainable Higher Education Research Alliance (SHERA) Program for Universitas Indonesia's Scientific Modeling, Application, Research, and Training for City-centered Innovation and Technology (SMART CITY) Project, Grant \#AID-497-A-1600004, Sub Grant \#IIE-00000078-UI-1. The authors would like to thank the University of Sriwijaya for funding this research. Also, the authors expressed their gratitude and appreciation to the civil engineering students under the supervise of authors who had assisted in field surveying and measuring work.

\section{REFERENCES}

Al Amin, M. B., \& Haki, H. (2017). Floodplain simulation for Musi River using integrated 1D/2D hydrodynamic model. MATEC Web of Conferences, 101, 5023. [Crossref]

Al Amin, M. B., Sarino, S., Haki, H., Ilmiaty, R. S., \& Marlina, A. (2018). Development of Flood Inundation Map Using UAV-Based DEM on Residential Area.

Al Amin, M. B., Sarino, S., \& Sari, N. K. (2015). Visualisasi Potensi Genangan Banjir di Sungai Lambidaro Melalui Penelusuran Aliran Menggunakan HEC-RAS Studi Pendahuluan Pengendalian Banjir Berwawasan Lingkungan.

Brunner, G. W. (2016). HEC-RAS river analysis system hydraulic reference manual, Ver. 5.0. Davis, CA, USA: US Army Corps of Engineers, Hydrologic Engineering Center, Cpd-69.

Brunner, G. W., Piper, S. S., Jensen, M. R., \& Chacon, B. (2015). Combined 1D and 2D hydraulic modeling within HEC-RAS. World Environmental and Water Resources Congress 2015, 1432-1443. [Crossref]

Elkhrachy, I. (2015). Flash Flood Hazard Mapping Using Satellite Images and GIS Tools: A case study of Najran City, Kingdom of Saudi Arabia (KSA). Egyptian Journal of Remote Sensing and Space Science, 18(2), 261-278. [Crossref]

Kreibich, H., Piroth, K., Seifert, I., Maiwald, H., Kunert, U., Schwarz, J., ... Thieken, A. H. (2009). Is flow velocity a significant parameter in flood damage modelling? Natural Hazards and Earth System Sciences (NHESS), 9(5), 1679-1692. [Crossref]

National Research Council. (2009). Mapping the zone: Improving flood map accuracy. National Academies Press. 
Oubennaceur, K., Chokmani, K., Nastev, M., Lhissou, R., \& Elalem, A. (2018). Flood risk mapping for direct damage to residential buildings in Quebec, Canada. International Journal of Disaster Risk Reduction. [Crossref]

Ovando, A., Martinez, J. M., Tomasella, J., Rodriguez, D. A., \& Randow, C. Von. (2018). Int J Appl Earth Obs Geoinformation Multi-temporal $\mathrm{fl}$ ood mapping and satellite altimetry used to evaluate the $\mathrm{fl}$ ood dynamics of the Bolivian Amazon wetlands. Int J Appl Earth Obs Geoinformation, 69(January), 27-40. [Crossref]

Ozkan, S. P., \& Tarhan, C. (2016). Detection of Flood Hazard in Urban Areas Using GIS: Izmir Case. Procedia Technology, 22, 373-381. [Crossref]

Patel, D. P., Ramirez, J. A., Srivastava, P. K., Bray, M., \& Han, D. (2017). Assessment of flood inundation mapping of Surat city by coupled 1D/2D hydrodynamic modeling: a case application of the new HECRAS 5. Natural Hazards, 89(1), 93-130. [Crossref]

Quirogaa, V. M., Kurea, S., Udoa, K., \& Manoa, A. (2016). Application of 2D numerical simulation for the analysis of the February 2014 Bolivian Amazonia flood: Application of the new HEC-RAS version 5. Ribagua, 3(1), 25-33. [Crossref]

Rahman, R., \& Thakur, P. K. (2018). The Egyptian Journal of Remote Sensing and Space Sciences Detecting , mapping and analysing of flood water propagation using synthetic aperture radar ( SAR ) satellite data and GIS : A case study from the Kendrapara District of Orissa State of India. The Egyptian Journal of Remote Sensing and Space Sciences, 21, S37-S41. [Crossref]

Ribeiro Neto, A., Batista, L. F. D. R., \& Coutinho, R. Q. (2016). Methodologies for generation of hazard indicator maps and flood prone areas: municipality of Ipojuca/PE. RBRH, 21(2), 377-390. [Crossref]

Situngkir, F., Sagala, S., Yamin, D., \& Widyasari, A. (2014). Spatial Relationship Between Land Use Change and Flood Occurrences in Urban Area of Palembang. Submit or Recommend next Manuscript to SCIRP and We Will Provide Best Service for You: Accepting Pre-Submission Inquiries through Email, Facebook, LinkedIn, Twitter, Etc. A Wide Selection of Journals (Inclusive of 9 Subjects, More than 200 Journals) Provi.

Solin, L., \& Skubincan, P. (2013). Flood risk assessment and management: review of concepts, definitions and methods. Geographical Journal, 65(1), 23-44.

Wallingford, H. (2005). Flood Risks to People Phase 2, The Flood Risk to People Methodology. Flood and Coastal Defence R\&D Programme. Department of the Environment, Flood and Rural Affairs--DEFRA, Londres, UK, 384.

Zhang, D., Quan, J., Zhang, H., Wang, F., Wang, H., \& He, X. (2015). Flash flood hazard mapping : A pilot case study in Xiapu River Basin , China. Water Science and Engineering, 8(3), 195-204. [Crossref] 